\title{
The Effect of Thyme Essential Oil (Thymus Vulgaris) Added to Quail Diets on Performance, Some Blood Parameters, and the Antioxidative Metabolism of the Serum and Liver Tissues
}

-Author(s)

\section{Gumus R \\ Ercan N"}

Imik HIII

Department of Animal Nutrition and Nutritional Disorders, Faculty of Veterinary Medicine, Cumhuriyet University, Sivas, Turkey.

" Department of Biochemistry, Faculty of Veterinary Medicine, Cumhuriyet University, Sivas, Turkey.

III Department of Animal Nutrition and Nutritional Disorders, Faculty of Veterinary Medicine, Ataturk University, Erzurum, Turkey.

\section{Mail Address}

Corresponding author e-mail address Assist. Prof. Recep Gumus

Department of Animal Nutrition and Nutritional Disorders, Faculty of Veterinary Medicine, Cumhuriyet University, Sivas, Turkey.

Tel: $\quad$ +90 346219 1010-2597

Email: recepgumus58@hotmail.com

\section{-Keywords}

Antioxidant, quail, liver, performance, thyme essential oil.

\section{ABSTRACT}

This study was conducted to determine the effect of diets containing different levels of thyme essential oil (TEO) on performance, some serum parameters and the antioxidative metabolism of the serum and liver tissues in quails. A total number of 200 sixteen-days-old Japanese quails (Coturnix coturnix japonica) were used in the study. The animals were divided into 4 groups; the control group was fed only basal diet but groups TEO1, TEO2 and TEO3 had thyme essential oil of 150, 300 and $450 \mathrm{mg} / \mathrm{kg}$, respectively, added to their diets. Body weight and daily weight gain increased with higher levels of thyme essential oil in the feed, yet a statistically significant increase was detected in only group TEO3 $(p<0.05)$. Furthermore, in all of the groups that were fed on TEO, feed intake was significantly higher than that of the control group $(p<0.05)$. In the groups that received thyme essential oil, serum creatinine and low-density lipoprotein (LDL) levels were low, whereas serum magnesium levels were high $(p<0.05)$. Thyme essential oil significantly increased in liver catalase (CAT), superoxide dismutase (SOD) and glutathione peroxidase (GSH-Px) activities and serum CAT and GSH-Px activities, and significantly reduced both liver and serum lipid peroxidation (malondialdehyde=MDA) levels $(p<0.01)$. In result, while thyme essential oil partially affected the performance and serum parameters, it had a marked effect on the antioxidant metabolism.

\section{INTRODUCTION}

For more than half a century antibiotics have been used as growthpromoting feed supplements to enhance yields in poultry production. However, once their detrimental effects on human and animal health were revealed, these synthetic growth promoters were replaced by alternative herbal products and in particular herbal extracts (essential oils) (Popović et al., 2016). Thyme (Thymus vulgaris) is one of these alternative medicinal herbs and is reported to increase appetite and feed intake as well as the secretion of endogenous digestive enzymes, and to strengthen the immune system when added to poultry feed, owing to the phenolic compounds it contains (Aeschbach et al., 1994; Cross et al., 2007; Brenes \& Roura, 2010).

Thymus vulgaris (thyme) is an aromatic plant of the Lamiaceae family and has received major attention as both a pharmaceutical and therapeutic agent across the globe. Reports indicate that the primary pharmacological effects of thyme arise from thymol and carvacrol, which are the most important bioactive compounds that this plant contains (Aeschbach et al., 1994; Grigore et al., 2010). The antioxidant property of bioactive compounds in the composition of thyme were determined in the laboratory analysis (Grosso et al., 2010). It is well known that thymol and carvacrol not only have an antioxidant effect 
but also antibacterial, antiviral and aroma regulatory effects (Aeschbach et al., 1994; Grossoet al., 2010). While some studies suggest that the supplementation of feed with thyme improves the performance parameters of poultry (Abd El-Latif et al., 2002; Tolba \& Hassan, 2003) some other studies suggest that thyme has no effect (Mehdipour et al., 2014; Saleh et al., 2014; Popović et al., 2016). Furthermore, thyme essential oil has also been reported that significantly reducing in levels of triglyceride, total cholesterol and glucose levels (Khaksar et al., 2012).

This study aimed to evaluate the effects of dietary supplementation of different levels of thyme essential oil on performance, some serum parameters with the antioxidative metabolism (SOD, CAT and GSH activities with MDA rate) of the serum and liver tissues in quails.

\section{MATERIAL AND METHODS}

\section{Animals, Experimental Design, and Diet}

This study was carried out with permission dated 13.02.2015 No. 15 with local Ethics Committee for Animal Experiments of the University of Cumhuriyet. The study design was conducted in the research and application center for Faculty of Veterinary Medicine in Cumhuriyet University. A total of 200 sixteen day old Japanese quail (Coturnix coturnix japonica), composed of 100 males and 100 females, constituted the material of the study. The quails were randomly allocated to one control group and three treatment groups (TEO1, TEO2 and TEO3) containing 50 quails. Each group was randomly divided into 5 subgroups, comprised of 10 quails ( 5 male, 5 female) each. The animals were housed in 20 five tier cages measuring $100 \times 45 \times 20 \mathrm{~cm}$. While the control group received a basal ration alone, groups TEO1, TEO2 and TEO3 were given a basal ration added with 150,300 and $450 \mathrm{mg} / \mathrm{kg}$ of thyme essential oil (Thyme oil ${ }^{\circledR}$, Ciftcizade Herbal Products Co., Antalya/ Turkey), respectively (Table 1). Animals in all groups were reared under the comfort temperature $\left(24^{\circ} \mathrm{C}\right)$ of the experimental period. Additionally, all groups were reared on a lighting cycle of $23 \mathrm{~h}$ light/d. The animals were provided with preweighed feed twice a day at 08:00 and 17:00 hours. Feed and water were provided ad libitum.

The quails received a basal diet that was formulated to meet the NRC (1994) requirements for nutrients including vitamins and minerals (Table 1). The nutritional composition of the diets was determined according to the AOAC (2005).
Table 1 - Formulation and analysis of the basal diet, \%

\begin{tabular}{|c|c|c|c|c|}
\hline \multirow{2}{*}{ Ingredient } & \multicolumn{4}{|c|}{ Groups } \\
\hline & Control & TEO1 & TEO2 & TEO3 \\
\hline Maize & 58.74 & 58.74 & 58.74 & 58.74 \\
\hline Maize gluten & 20.00 & 20.00 & 20.00 & 20.00 \\
\hline Wheat bran & 7 & 6.985 & 6.970 & 6.955 \\
\hline Soybean oil & 3.72 & 3.72 & 3.72 & 3.72 \\
\hline Soybean meal & 7.14 & 7.14 & 7.14 & 7.14 \\
\hline Calcium carbonate & 1.23 & 1.23 & 1.23 & 1.23 \\
\hline Dicalcium phosphate & 0.91 & 0.91 & 0.91 & 0.91 \\
\hline L-lysine & 0.42 & 0.42 & 0.42 & 0.42 \\
\hline Sodium chloride & 0.27 & 0.27 & 0.27 & 0.27 \\
\hline Vitamin-mineral premix** & 0.20 & 0.20 & 0.20 & 0.20 \\
\hline Toxin binder & 0.10 & 0.10 & 0.10 & 0.10 \\
\hline Coccidiostat & 0.10 & 0.10 & 0.10 & 0.10 \\
\hline Sodium bicarbonate & 0.09 & 0.09 & 0.09 & 0.09 \\
\hline Growth factor & 0.05 & 0.05 & 0.05 & 0.05 \\
\hline Phyzyme XP TPT & 0.03 & 0.03 & 0.03 & 0.03 \\
\hline Thyme oil* & - & 0.015 & 0.030 & 0.045 \\
\hline \multicolumn{5}{|l|}{ Calculated nutrient contents } \\
\hline Metabolisable energy (MJ/kg) & 13.40 & 13.40 & 13.40 & 13.40 \\
\hline Crude protein \% & 21 & 21 & 21 & 21 \\
\hline Ether extract \% & 6.37 & 6.37 & 6.37 & 6.37 \\
\hline Crude fibre \% & 2.68 & 2.68 & 2.68 & 2.68 \\
\hline Methionine \% & 0.43 & 0.43 & 0.43 & 0.43 \\
\hline Lysine \% & 1.00 & 1.00 & 1.00 & 1.00 \\
\hline Calcium \% & 0.90 & 0.90 & 0.90 & 0.90 \\
\hline Phosphorus \% & 0.65 & 0.65 & 0.65 & 0.65 \\
\hline
\end{tabular}

*the thyme essential oil were added in place of wheat bran.

** the vitamin-mineral premix provides the following (per $\mathrm{kg}$ ): all-transretinyl acetate $1.8 \mathrm{mg}$; all-rac- $\alpha$-tocopherol acetate $1.25 \mathrm{mg}$; menadione sodium bisulphate $1.1 \mathrm{mg}$; riboflavin $4.4 \mathrm{mg}$; thiamine (thiamine mononitrate) $1.1 \mathrm{mg}$; vitamin B6 $2.2 \mathrm{mg}$; niacin 35 mg; Ca-pantothenate 10 mg; vitamin B12 0.02 mg; folic acid 0.55 mg; d-biotin $0.1 \mathrm{mg}$; choline chloride $175 \mathrm{mg}$; manganese (from manganese oxide) 40 mg; iron (from iron sulphate) $12.5 \mathrm{mg}$; zinc (from zinc oxide) $25 \mathrm{mg}$; copper (from copper sulphate) $3.5 \mathrm{mg}$; iodine (from potassium iodide) $0.3 \mathrm{mg}$; selenium (from sodium selenite) $0.15 \mathrm{mg}$.

\section{Performance Parameters}

The birds were weighed at the beginning of the experiment ( 16 days-old) and on days $23,30,37,44$ and 51 of age in the morning, before they were given feed. Body weight gain was calculated on weekly basis throughout the experimental period of 16-51 days of age. Mortality was recorded when it occurred. In order to determine the daily feed consumption of the animals, throughout the experimental period, weighed quantities of feed were provided in the morning and evening and the remainder collected the following day was weighed and subtracted from the amount of feed provided. As the subgroups included ten animals, individual daily feed intake was calculated by dividing the daily feed intake values by ten. The feed conversion ratio (FCR) was calculated as $\mathrm{g}$ feed per g body weight gain. 


\section{Biochemical Analyses}

\section{Collection of Blood and Liver Tissue Samples}

Male quails grow up faster than female quails. Therefore, it can be thought that the experiment, ten male quails selected randomly from every group were decapitated, and the analyses were made on their blood and liver tissues (prior to slaughter, the quails were fasted for $12 \mathrm{~h}$ ). Blood samples were collected from jugular vein on the last day of the trial, for use in biochemical analyses. The blood samples, collected in volumes of 5 cc into dry tubes (Becton Dickinson Co. USA), were centrifuged at $+4{ }^{\circ} \mathrm{C}$ and $4000 \mathrm{rpm}$ for 10 minutes in a cooled centrifuge (Hettich 38R, Hettich Zentrifugen, Tuttlingen, Germany). The harvested serum samples were stored at $-80^{\circ} \mathrm{C}$ until use. Liver tissue was homogenized by using liquid nitrogen and then stored at $-80^{\circ} \mathrm{C}$ until the biochemical investigations.

\section{Determination of Serum Biochemical Parameters}

Serum concentrations of glucose, total protein, albumin, urea, creatinine, cholesterol, triglycerides, high density lipoprotein (HDL), LDL, calcium, magnesium, phosphorus and iron were measured with an automatic analyzer using commercial test kits (Mindray BS 200, PRC).

\section{Antioxidant Enzymes}

\section{Determination of Lipid Peroxidation (LP) by Malondialdehyde (MDA)}

MDA measurement was done following Yu \& Sinnhuber (1986) method. The principle of this method is based on the measurement of the absorbance of the color that MDA forms with thiobarbituric acid (TBA) in acidic media. For this purpose, $300 \mu \mathrm{L}$ of samples were taken, $300 \mu \mathrm{L}$ of $10 \%$ phosphotungstic acid and 2,4 $\mathrm{mL}$ of $0,084 \mathrm{M}$ sulfuric acid solutions were added to them and they were incubated at $95^{\circ} \mathrm{C}$ for 45 minutes. After cooling the samples, they were measured spectrophotometric of the absorbance at $532 \mathrm{~nm}$. 1 mmol 1,1,3,3, tetrametoksipropan was incubated in $100 \mathrm{~mL} \mathrm{0,01} \mathrm{M} \mathrm{HCl}$ at $50{ }^{\circ} \mathrm{C}$ for 1 hour and 20, 10, 5, $2.5,1.25,0.625 \mathrm{nmol} / \mathrm{L}$ work standards were prepared using the MDA solution that has been formed through the hydrolysis of this compound. The graph of the standard was drawn using these outcomes and MDA results were calculated through this graph.

\section{SOD Activity}

The method developed by Sun et al. (1988) was used for the determination of superoxide dismutase
(SOD) activity in the tissue taken from the quails. The principle of the method, is to compose formazan by reducing the colorants, such as nitro blue tetrazolium (NBT), that are formed during the oxidation of xanthine oxidase (XO) with xanthine. The formed NBT is based on the spectrophotometric measure of the absorbance of the color at $560 \mathrm{~nm}$.

\section{Catalase Activity}

Catalase activity was calculated using Aebi's (1983) method. $50 \mathrm{mM}$ phosphate buffer with pH 7.0 was prepared; also $30 \mathrm{mM}$ hydrogen peroxide solution was prepared. $1 \mathrm{~mL} \mathrm{H}_{2} \mathrm{O}_{2}$ was added to $2 \mathrm{~mL}$ sample whereas $1 \mathrm{~mL}$ phosphate buffer was added to the formed solution and measurements were made spectrophotometric of the absorbance at $230 \mathrm{~nm}$.

\section{GSH-Px Activity}

Glutathione is a chemical substance with tripeptide structure and it is mostly found in animals. Glutathione is an important molecule that acts as an electron donor for enzyme glutathione peroxidase, which is used in the detoxification of harmful molecules in biochemical metabolism. Catalytic activity detection was performed according to the method of Paglia \& Valantine (1967). The decrease of NADPH's absorbance was monitored spectrophotometric measure of the absorbance at 340 $\mathrm{nm}$ and determined kinetically.

\section{Statistical Analysis}

The data obtained was assessed using the SPSS 20 software (SPSS, 2011). Differences between the groups were determined with the one-way analysis of variance (ANOVA) test and Duncan's post-test. The data were expressed as mean \pm standard error of mean (SEM). Differences were considered with significant at $p<0.05, p<0.01$.

\section{RESULTS}

Of the performance parameters investigated in this study, body weight, daily weight gain, feed intake and feed conversion ratio data are presented in Table 2. As it can be seen in this table, when incorporated into feed at a level of $450 \mathrm{mg} / \mathrm{kg}$, thyme essential oil significantly increased body weight on days 30, 37 and 44 of the study, and daily weight gain throughout the trial, excluding the periods between days 3037 and $44-51 \quad(p<0.05)$. It was observed that feed intake had significantly increased in only group TEO1 between days $44-51(p<0.05)$ and in all of the groups that received thyme during the other time periods 
The Effect of Thyme Essential Oil (Thymus Vulgaris) Added to Quail Diets on Performance, Some Blood Parameters, and the Antioxidative Metabolism of the Serum and Liver Tissues

Table 2 - Effects of basal diets supplemented with thyme essential oil on body weight, body weight gain, feed intake and feed conversion ratio in quails.

\begin{tabular}{|c|c|c|c|c|c|}
\hline \multirow{2}{*}{ Performance parameters } & \multicolumn{4}{|c|}{ Groups } & \multirow{2}{*}{$p$ value } \\
\hline & Control & TEO1 & TEO2 & TEO3 & \\
\hline \multicolumn{6}{|l|}{ Body weight, g } \\
\hline Initial (16 d) & $104,72 \pm 1,98$ & $104,48 \pm 1,10$ & $104,82 \pm 3,04$ & $104,20 \pm 3,81$ & ns \\
\hline $23 \mathrm{~d}$ & $152,60 \pm 3,84$ & $154,10 \pm 1,78$ & $155,46 \pm 2,58$ & $158,38 \pm 3,31$ & ns \\
\hline $30 d$ & $193,88 \pm 4,68^{b}$ & $198,20 \pm 2,23^{\mathrm{ab}}$ & $200,04 \pm 2,36^{\mathrm{ab}}$ & $205,06 \pm 3,00^{a}$ & * \\
\hline $37 d$ & $225,32 \pm 6,88^{b}$ & $232,54 \pm 3,63^{a b}$ & $233,32 \pm 3,40^{\mathrm{ab}}$ & $241,90 \pm 4,41^{\mathrm{a}}$ & * \\
\hline $44 d$ & $234,76 \pm 7,58^{b}$ & $239,94 \pm 4,58^{b}$ & $250,98 \pm 3,76^{\mathrm{ab}}$ & $262,64 \pm 3,82^{\mathrm{a}}$ & * \\
\hline Final $(51 \mathrm{~d})$ & $252,53 \pm 4,88$ & $262,08 \pm 5,60$ & $266,78 \pm 6,04$ & $269,94 \pm 5,03$ & ns \\
\hline \multicolumn{6}{|l|}{ Body weight gain, g/day } \\
\hline $16-23 d$ & $6,84 \pm 0,36^{b}$ & $7,09 \pm 0,12^{\mathrm{ab}}$ & $7,23 \pm 0,19^{\mathrm{ab}}$ & $7,74 \pm 0,19^{a}$ & * \\
\hline $23-30 d$ & $5,90 \pm 0,21^{b}$ & $6,30 \pm 0,13^{\mathrm{ab}}$ & $6,37 \pm 0,16^{\mathrm{ab}}$ & $6,67 \pm 0,22^{\mathrm{a}}$ & * \\
\hline $30-37 d$ & $4,49 \pm 0,35$ & $4,90 \pm 0,26$ & $4,75 \pm 0,28$ & $5,26 \pm 0,27$ & ns \\
\hline $37-44 d$ & $1,35 \pm 0,27^{b c}$ & $1,06 \pm 0,57^{c}$ & $2,52 \pm 0,57^{\mathrm{ab}}$ & $2,96 \pm 0,33^{\mathrm{a}}$ & * \\
\hline $44-51 d$ & $2,54 \pm 0,64^{\mathrm{ab}}$ & $3,15 \pm 0,56^{a}$ & $2,26 \pm 0,71^{\mathrm{ab}}$ & $1,04 \pm 0,30^{b}$ & * \\
\hline $16-51 d$ & $4,22 \pm 0,16^{b}$ & $4,50 \pm 0,13^{\mathrm{ab}}$ & $4,63 \pm 0,14^{\mathrm{ab}}$ & $4,74 \pm 0,19^{a}$ & * \\
\hline \multicolumn{6}{|l|}{ Feed intake, g/day } \\
\hline $16-23 d$ & $17,31 \pm 0,15^{c}$ & $17,66 \pm 0,07^{a b}$ & $17,97 \pm 0,08^{\mathrm{ab}}$ & $18,03 \pm 0,10^{a}$ & ** \\
\hline $23-30 d$ & $19,26 \pm 0,11^{c}$ & $19,71 \pm 0,05^{b}$ & $20,17 \pm 0,08^{a}$ & $20,20 \pm 0,08^{\mathrm{a}}$ & ** \\
\hline $30-37 d$ & $22,23 \pm 0,04^{b}$ & $22,68 \pm 0,05^{a}$ & $22,80 \pm 0,09^{a}$ & $22,77 \pm 0,08^{a}$ & ** \\
\hline $37-44 d$ & $23,46 \pm 0,05^{c}$ & $23,97 \pm 0,08^{b}$ & $24,46 \pm 0,12^{a}$ & $24,37 \pm 0,15^{a}$ & ** \\
\hline $44-51 d$ & $25,23 \pm 0,12^{b}$ & $26,20 \pm 0,09^{a}$ & $25,63 \pm 0,29^{b}$ & $25,74 \pm 0,17^{\mathrm{ab}}$ & * \\
\hline $16-51 d$ & $21,50 \pm 0,03^{c}$ & $22,05 \pm 0,05^{b}$ & $22,21 \pm 0,09^{a b}$ & $22,22 \pm 0,03^{a}$ & ** \\
\hline \multicolumn{6}{|c|}{ Feed conversion ratio, g feed / g gain } \\
\hline $16-51 \mathrm{~d}$ & $5,12 \pm 0,18$ & $4,91 \pm 0,14$ & $4,82 \pm 0,15$ & $4,73 \pm 0,22$ & ns \\
\hline
\end{tabular}

All values are given as mean \pm standard error of mean $(S E M),(n=5)$. ns: not significant $(p>0.05)$.

$a, b$ : A letter in the same line means significantly different $\left.\left({ }^{*}: p<0.05\right),{ }^{* *}: p<0.01\right)$.

Control: basal ration alone, TE01: basal ration+150 mg/kg of thyme essential oil, TEO2: basal ration+300 mg/kg of thyme essential oil, TEO3: basal ration+450 mg/kg of thyme essential oil.

investigated $(p<0.01)$. The data obtained in this study revealed that the feed conversion ratio was similar in all study groups ( $p>0.05$ ), yet thyme essential oil was shown to have a quantitatively positive effect (Table 2 ).
The investigation of serum parameters demonstrated that the glucose, total protein, albumin, urea, cholesterol, triglyceride, HDL, calcium, phosphorus and iron levels were similar in the control group and

Table 3 - Effects of basal diets supplemented with thyme essential oil on some serum biochemical parameters in male quails.

\begin{tabular}{|c|c|c|c|c|c|}
\hline \multirow{2}{*}{ Parameters } & \multicolumn{4}{|c|}{ Groups } & \multirow{2}{*}{$p$ value } \\
\hline & Control & TEO1 & TEO2 & TEO3 & \\
\hline Glucose mg/dL & $334,60 \pm 7,62$ & $353,40 \pm 11,90$ & $352,50 \pm 8,17$ & $355,60 \pm 7,07$ & ns \\
\hline Total Protein g/L & $2,85 \pm 0,07$ & $3,01 \pm 0,13$ & $2,87 \pm 0,58$ & $2,88 \pm 0,12$ & ns \\
\hline Albumin g/L & $1,04 \pm 0,03^{\mathrm{ab}}$ & $1,11 \pm 0,02^{\mathrm{a}}$ & $1,03 \pm 0,03^{a b}$ & $1,02 \pm 0,03^{b}$ & * \\
\hline Urea mmol/L & $10,74 \pm 0,60$ & $10,35 \pm 0,75$ & $9,27 \pm 0,48$ & $9,90 \pm 1,19$ & ns \\
\hline Creatinine mg/dL & $0,64 \pm 0,01^{\mathrm{a}}$ & $0,57 \pm 0,04^{b}$ & $0,48 \pm 0,02^{c}$ & $0,49 \pm 0,02^{c}$ & ** \\
\hline Cholesterol mg/dL & $197,51 \pm 7,42^{\mathrm{ab}}$ & $218,88 \pm 11,22^{\mathrm{a}}$ & $180,51 \pm 7,32^{b}$ & $187,74 \pm 8,75^{b}$ & * \\
\hline Triglyceride $\mathrm{mg} / \mathrm{dL}$ & $150,45 \pm 14,07$ & $251,09 \pm 68,58$ & $145,46 \pm 9,64$ & $204,45 \pm 35,39$ & ns \\
\hline $\mathrm{HDL} \mathrm{mg/dL}$ & $146,87 \pm 6,24$ & $155,73 \pm 12,05$ & $139,26 \pm 4,88$ & $142,34 \pm 9,07$ & ns \\
\hline LDL mg/dL & $35,46 \pm 4,89^{a}$ & $24,27 \pm 3,37^{b}$ & $29,06 \pm 2,06^{\mathrm{ab}}$ & $20,91 \pm 3,77^{b}$ & * \\
\hline Ca mg/dL & $9,12 \pm 0,14$ & $10,51 \pm 1,09$ & $9,25 \pm 0,14$ & $11,09 \pm 1,18$ & ns \\
\hline $\mathrm{Mg} \mathrm{mg/dL}$ & $5,32 \pm 0,07^{b}$ & $5,51 \pm 0,12^{b}$ & $5,77 \pm 0,09^{a}$ & $5,86 \pm 0,08^{a}$ & ** \\
\hline $\mathrm{P} \mathrm{mg} / \mathrm{dL}$ & $5,02 \pm 0,28$ & $4,92 \pm 0,29$ & $4,68 \pm 0,29$ & $4,52 \pm 0,27$ & ns \\
\hline $\mathrm{Fe} \mu \mathrm{mol} / \mathrm{L}$ & $21,06 \pm 2,93$ & $22,30 \pm 2,10$ & $19,93 \pm 2,15$ & $16,99 \pm 1,16$ & ns \\
\hline
\end{tabular}

All values are given as mean \pm standard error of mean $(S E M),(n=10)$. ns: not significant $(p>0.05)$.

$a, b, c:$ A letter in the same line means significantly different $(*: p<0.05),(* *: p<0.01)$.

Control: basal ration alone, TE01:basal ration+150 mg/kg of thyme essential oil, TEO2: basal ration+300 mg/kg of thyme essential oil, TE03: basal ration+450 mg/kg of thyme essential oil. 
the groups that were fed on thyme ( $p>0.05)$ (Table 3 ). Creatinine levels were ascertained to have significantly decreased in groups TEO1 $(p<0.05)$, TEO2 and TEO3 $(p<0.01)$ (Table 3). LDL levels had significantly decreased in groups TEO1 and TEO3, whilst magnesium levels had significantly increased in groups TEO2 and TEO3 $(p<0.05)$ (Table 3).

In all of the groups that received thyme, hepatic CAT $(p<0.05), S O D$ and GSH-Px activities had significantly increased $(p<0.01)$, while MDA levels had decreased $(p<0.01)$ (Table 4). Serum analyses showed that while thyme essential oil had no effect on SOD activity, it observed significantly increased in activities of CAT and GSH-Px and significantly decreased MDA levels in all groups $(p<0.01)$ (Table 4$)$.

\section{DISCUSSION}

Based on recent research, which has shown the occurrence of detrimental effects on human and animal health with the long-term use of synthetic growth promoters, these synthetic compounds have been replaced by phytogenic feed supplements (herbs, essential oil, extracts, powders, etc.) (Brenes \& Roura, 2010; Hashemi \& Davoodi, 2010; Popović et al., 2016). It has been reported that, when used as a growth promoter, thyme significantly improves body weight and feed conversion ratios in both broiler chickens (Tolba \& Hassan, 2003) and quails (Abd El-Latif et al., 2002). In the present study, when incorporated into feed at a level of $450 \mathrm{mg} / \mathrm{kg}$, thyme essential oil significantly increased body weight on days 30, 37 and 44 , and daily weight gain throughout the study period, excluding the intervals between days 30-37 and 44-51
Table 2). Previous studies have shown that, when quail rations were supplemented with $100 \mathrm{mg} / \mathrm{kg}$ of thyme extract (Mehdipour et al., 2014) and broiler rations were supplemented with 100 and $200 \mathrm{mg} / \mathrm{kg}$ of thyme essential oil, neither body weight not daily weight gain were affected (Saleh et al., 2014). Furthermore, it has been reported that thyme powder significantly increases body weight when incorporated into feed at a level of $5 \mathrm{~g} / \mathrm{kg}$ (Toghyani et al., 2010); and significantly increases both body weight and daily weight gain when added to feed rations at percentages of $0.5,1$, 1.5 and 2\% (Safa \& Al-Beitawi, 2009). In the present study, the greatest increase in body weight and daily weight gain was determined in the trial group that received $450 \mathrm{mg} / \mathrm{kg}$ of thyme essential oil. The results of the present study were found to be in agreement with those of previous studies, which revealed that thyme did not affect body weight when fed at low levels (Mehdipour et al., 2014; Saleh et al., 2014), but showed an increasingly significant effect when given at higher levels (Safa \& Al-Beitawi, 2009; Toghyani et al., 2010).

Thymol shows the ability to protect the microvilli, which are responsible for the absorption of nutrients and stimulate the appetite, positively affect the secretion of endogenous digestive (Hashemipour et al., 2013). The results of the present study showed that the feed intake of the groups that received thyme essential oil had significantly increased in comparison to the control group throughout the study period excluding the interval between days 44 and 51 . Similar to the results obtained in the present study, Saleh et al. (2014) determined that the supplementation of feed with 100 and $200 \mathrm{mg} / \mathrm{kg}$ of thyme essential oil

Table 4 - Effects of basal diets supplemented with thyme essential oil on antioxidant enzymes in serum and liver tissues of male quails

\begin{tabular}{|c|c|c|c|c|c|}
\hline \multirow{2}{*}{ Parameters } & \multicolumn{4}{|c|}{ Groups } & \multirow{2}{*}{$p$ value } \\
\hline & Control & TEO1 & TEO2 & TEO3 & \\
\hline \multicolumn{6}{|l|}{ Liver } \\
\hline CAT U/mg pro & $5,68 \pm 1,02^{b}$ & $13,74 \pm 2,49^{a}$ & $13,10 \pm 1,85^{a}$ & $16,44 \pm 5,51$ & * \\
\hline SOD U/g pro & $1,04 \pm 0,12^{b}$ & $1,45 \pm 0,10^{a}$ & $1,63 \pm 0,92^{a}$ & $1,45 \pm 0,09^{a}$ & ** \\
\hline GSH-Px U/g pro & $119,55 \pm 11,70^{c}$ & $397,96 \pm 81,73^{b}$ & $301,64 \pm 32,39^{b}$ & $571,61 \pm 153,44^{a}$ & ** \\
\hline MDA nmol/g & $11,60 \pm 3,25^{a}$ & $3,08 \pm 0,34^{b}$ & $4,82 \pm 0,64^{b}$ & $5,16 \pm 0,61^{b}$ & $* *$ \\
\hline \multicolumn{6}{|l|}{ Serum } \\
\hline CAT U/ml & $6,51 \pm 1,63^{b}$ & $22,89 \pm 4,83^{a}$ & $19,35 \pm 2,99^{a}$ & $15,51 \pm 1,62^{a}$ & $* *$ \\
\hline SOD U/ml & $0,68 \pm 0,02$ & $0,72 \pm 0,02$ & $0,71 \pm 0,04$ & $0,74 \pm 0,03$ & ns \\
\hline GSH-Px U/ml & $826,80 \pm 53,77^{b}$ & $1199,38 \pm 149,12^{a}$ & $1146,94 \pm 49,69^{a}$ & $1391,76 \pm 55,17^{a}$ & $* *$ \\
\hline MDA nmol/ml & $8,29 \pm 0,28^{a}$ & $6,25 \pm 0,49^{b}$ & $5,60 \pm 0,27^{b}$ & $5,53 \pm 0,50^{b}$ & ** \\
\hline
\end{tabular}

All values are given as mean \pm standard error of mean $(S E M),(n=10)$. $n s$ : not significant $(p>0.05)$.

$a, b, c:$ A letter in the same line means significantly different $\left({ }^{*}: p<0.05\right),\left({ }^{*}: p<0.01\right)$.

Control: basal ration alone, TE01: basal ration+150 mg/kg of thyme essential oil, TEO2: basal ration+300 mg/kg of thyme essential oil, TEO3: basal ration+450 mg/kg of thyme essential oil. 
significantly increased feed intake but did not affect the feed conversion ratio. In further studies carried out in broiler chickens, it was reported that thyme did not affect feed intake (Toghyani et al., 2010) but significantly improved the feed conversion ratio (Tolba \& Hassan, 2003; Toghyani et al., 2010). On the other hand, it was also reported that $100 \mathrm{mg} / \mathrm{kg}$ of thyme extract (Mehdipour et al., 2014) and $1 \mathrm{~g} / \mathrm{kg}$ of thyme essential oil did not alter the feed intake or feed conversion ratio of quails (Khaksar et al., 2012). The differences observed between the results of these studies are attributed to possible differences in the form (extract, powder, etc.), content and amount of thyme used.

It has been reported that the thymol and carvacrol content of thyme slows down the activity of the cholesterol-synthesizing enzyme Hydroxymethylglutaryl Coenzyme A reductase, and thereby, decreases cholesterol levels (Elson, 1995). In agreement with this finding, it has also been reported that thyme significantly decreases cholesterol and triglyceride levels in quails (Khaksar et al., 2012), broiler chickens (Safa \& Al-Beitawi, 2009) and laying hens (Ali et al., 2007). On the other hand, it has also been indicated that the incorporation of 5 and $10 \mathrm{~g} / \mathrm{kg}$ of thyme powder into broiler rations did not affect serum levels of triglyceride, cholesterol or LDL; whereas $10 \mathrm{~g} / \mathrm{kg}$ of thyme powder significantly increased HDL cholesterol levels (Toghyani et al., 2010). Another report indicated that 100, 200 and $300 \mathrm{mg} / \mathrm{kg}$ of thyme essential oil did not have any effect on serum LDL and HDL levels in broiler chickens (Saleh et al., 2014). Lee et al. (2003) reported that while thymol did not affect plasma triglyceride and phospholipid levels, carvacrol significantly decreased these parameters in broiler chickens, owing to its major effect on lipogenesis rather than its effect on cholesterol biosynthesis. Although the significant decrease observed in the serum LDL levels of the groups that received 150 and $450 \mathrm{mg} /$ $\mathrm{kg}$ of thyme essential oil in the present study is proof of the possible effect of thyme on the hypolipidemic mechanism, thyme essential oil having not shown any effect on cholesterol, triglyceride or HDL levels shows that there is need for further detailed studies for a better interpretation.

Similar to previous studies in broiler chickens, in the present study, serum urea (Saleh et al., 2014) and albumin levels were not affected by feed supplementation with thyme essential oil (Safa \& AlBeitawi, 2009; Toghyani et al., 2010; Saleh et al., 2014). It has been reported that thyme essential oil and thyme powder significantly increase serum total protein (Safa \& Al-Beitawi, 2009; Saleh et al., 2014) and glucose levels (Safa \& Al-Beitawi, 2009). In the present study, it was determined that thyme essential oil led to an increase mathematically in these parameters. Khaksar et al. (2012) reported that thyme essential oil did not have any effect on serum calcium levels in quails. Similar to this report, in the present study, it was ascertained that neither calcium nor phosphorus and iron levels had changed, whereas magnesium levels had significantly increased (Table 3). In general, on the basis of an assessment of available research results, it can be stated that the effects of thyme are variable, which could be attributed to differences in the amount of thyme and the particular animal species used in studies.

It is well known that free radicals (superoxide, hydroxyl, hydrogen peroxide etc.) are generated as a result of normal metabolic activity and are eliminated by various routes. However, in the event of antioxidant deficiency and the generation of an excessive amount of free radicals due to stress factors, these radicals cause both tissue damage and the lipid peroxidation (LPO) of fatty acids. LPO is an irreversible reaction process, which is initiated by the oxidation of polyunsaturated fatty acids and continues with autocatalytic chain reactions and causes damage to several biological structures. Therefore, it is the most significant indicator of oxidative stress (Sies, 1997). Intensive production methods aimed at increasing the production performance of animals accelerate metabolic activity and bring about an increase in the level of free radicals generated. Owing to the phenolic compounds (thymol and carvacrol) it contains, thyme (Thymus vulgaris) has antioxidant (Lawrence, 2005), antimicrobial and antifungal effects, which aid in maintaining health (Basilico \& Basilico, 1999; Criag, 1999). Research has shown that the thymol and carvacrol content of thyme essential oil significantly reduces lipid peroxidation in tissues (Yanishlieva et al., 1999; Nieto et al., 2011). In the present study, the assessment of the effects of thyme essential oil on the activity of the antioxidant enzymes CAT and SOD, which protect tissues against oxidation, and the enzyme GSH-Px, which protects intracellular lipids against peroxidation, demonstrated that thyme essential oil significantly increased the hepatic activity of all three enzymes and the serum activity of CAT and GSH-Px. Furthermore, as the most significant indicator of lipid peroxidation, it was determined that MDA levels had significantly decreased in both the liver and serum. The findings 
obtained in the present study are in agreement with those obtained in previous researches, and thus, it is suggested that thyme essential oil, in general, has positive effects on the antioxidant metabolism.

\section{CONCLUSIONS}

As a conclusion, although the supplementation of quail rations with thyme essential oil $(150,300$ and $450 \mathrm{mg} / \mathrm{kg}$ ) significantly increased feed intake, it was determined that only a supplementation level of 450 $\mathrm{mg} / \mathrm{kg}$ affected body weight and daily weight gain. It was ascertained that thyme essential oil showed a significant antioxidant effect in the serum and liver and significantly reduced the level of MDA, which is an indicator of tissue lipid peroxidation. Also, another important finding in relation to the serum parameters was the decrease observed in the LDL levels. The results of the present study, which demonstrated that thyme essential oil markedly affects the antioxidant metabolism, are considered to provide contribution to future studies on this topic.

\section{ACKNOWLEDGEMENTS}

This work is supported by the Scientific Research Project Fund of Cumhuriyet University under the project number ' $\mathrm{V}-026$ '.

\section{REFERENCES}

Abd El-Latif SA, Ahmed FA, El-Kaiaty AM. Effect of feeding dietary thyme, black cumin, dianthus and fennel on productive and some metabolic responses of growing japanese quail. Egyptian Poultry Science Journal 2002;22(1):109-125

Aebi HE. Catalase. In: Bergmeyer UH, Bergmeyer J., Grassl M. Method of enzymatic analysis. Michigan: Verlag Chemie; 1983. v.3, p.273-286.

Aeschbach R, Loliger J, Scott BC, Muscia A, Butler J, Halliwell B. Antioxidant action of thymol, carvacrol, 6- ginerol, zinezerone and hydroxytyrosol. Food and Chemical Toxicology 1994;32(1):31-36.

Ali MN, Hassan MS, El-Ghany FA. Effect of strain, type of natural antioxidant and sulphate ion on productive, physiological and hatching performance of native laying hens. International Journal of Poultry Science 2007;6(8):539-554.

AOAC. Official methods of analysis of AOAC International. $18^{\text {th }}$ ed. Rockville: AOAC International; 2005

Basilico MZ, Basilico JC. Inhibitory effects of some spice essential oils on Aspergillus ochraceus NRRL 3174 growth and ochratoxin A production. Letters in Applied Microbiology 1999;29(4):238-241.

Brenes A, Roura E. Essential oils in poultry nutrition:Main effects and modes of action. Animal Feed Science and Technology 2010;158(1):1-14.

Criag WJ. Health-promoting properties of common herbs. American Journal of Clinical Nutrition 1999;70:491-499.
Cross DE, McDevitt RM, Hillman K, Acamovic T. The effect of herbs and their associated essential oils on performance, dietary digestibility and gut microflora in chickens from 7 to 28 days of age. British Poultry Science 2007;48(4):496-506

Elson CE. Suppression of mevalonate pathway activities by dietary isoprenoids:protective roles in cancer and cardiovascular disease. The Journal of Nutrition 1995;125(6):1666-1672

Grigore A, Paraschiv INA, Colceru-Mihul S, Bubueanu C, Draghici E, Ichim M. Chemical composition and antioxidant activity of Thymus vulgaris $L$. volatile oil obtained by two different methods. Romanian Biotechnological Letters 2010;15(4):5436-5443.

Grosso C, Figueiredo AC, Burillo J, Mainar AM, Urieta JS, Barroso JG, et al. Composition and antioxidant activity of Thymus vulgaris volatiles:comparison between supercritical fluid extraction and hydrodistillation. Journal of Separation Science 2010;33(14):22112218.

Hashemi SR, Davoodi H. Phytogenics as new class of feed additive in poultry industry. Journal of Animal and Veterinary Advances 2010;9(17):22952304.

Hashemipour H, Kermanshahi H, Golian A, Raji A, Vankrimpen MM. Effect of thymol+carvacrol by next enhance $150^{\circledR}$ on intestinal development of broiler chickens fed CMC containing diet. Iranian Journal Applied of Animal Science 2013;3:567-576.

Khaksar V, Krimpen MV, Hashemipour H, Pilevar M. Effects of thyme essential oil on performance, some blood parameters and ileal microflora of Japanese quail. The Journal of Poultry Science 2012;49(2):106-110.

Lawrence BM. Antimicrobial/biological activity of essential oils. Illinois: Allured Publishing Corporation; 2005.

Lee KW, Everts H, Kappert HJ, Yeom KH, Beynen AC. Dietary carvacrol lowers body weight gain but improves feed conversion in female broiler chickens. The Journal of Applied Poultry Research 2003;12(4):394-399.

Mehdipour Z, Afsharmanesh M, Sami M. Effects of supplemental thyme extract (Thymus vulgaris L.) on growth performance, intestinal microbial populations, and meat quality in Japanese quails. Comparative Clinical Pathology 2014;23(5):1503-1508.

Nieto G, Bañón S, Garrido MD. Effect of supplementing ewes' diet with thyme (Thymus zygis ssp. gracilis) leaves on the lipid oxidation of cooked lamb meat. Food Chemistry 2011;125(4):1147-1152.

NRC. National Research Council. Nutrient requirements of poultry. 9th rev. ed. Washington: National Academy Press; 1994.

Paglia DE, Valentine WN. Studies on the quantitative and qualitative characterization of erythrocyte glutathione peroxidase. The Journal of Laboratory and Clinical Medicine 1967;70(1):158-169.

Popović S, Puvača N, Kostadinović L, Džinić N, Bošnjak J, Vasiljević M, et al. Effects of dietary essential oils on productive performance, blood lipid profile, enzyme activity and immunological response of broiler chickens. European Poultry Science 2016;80:1-12.

Safa SEG, AL-Beitawi NA. The effect of feeding of crushed thyme (Thymus valgaris) on growth, blood constituents, gastrointestinal tract and carcass characteristics of broiler chickens. Journal of Poultry Science 2009;4:100-104.

Saleh, N, Allam T, El-latif AA, Ghazy E. The effects of dietary supplementation of different levels of thyme (Thymus vulgaris) and ginger (Zingiber officinale) essential oils on performance, hematological, biochemical and immunological parameters of broiler chickens. Global Veterinaria 2014;12(6):736-744 
Sies H. Oxidative stress:oxidants and antioxidants. Experimental Physiology 1997;82(2):291-295

SPSS. Statistical packages for the social sciences. 20th ed. Chicago: IBM; 2011.

Sun YI, Oberley LW, Li Y. A simple method for clinical assay of superoxide dismutase. Clinical Chemistry 1988;34(3):497-500.

Toghyani M, Tohidi M, Gheisari AA, Tabeidian SA. Performance, immunity, serum biochemical and hematological parameters in broiler chicks fed dietary thyme as alternative for an antibiotic growth promoter. African Journal of Biotechnology 2010;9(40):6819-6825.
Tolba AAH, Hassan MSH. Using some natural additives to improve physiological and productive performance of broiler chicks under high temperature conditions. 2-Black cumuin (Nigella sativa) or garlic (Allium sativum). Egyptian Poultry Science Journal 2003;23:327-340.

Yanishlieva NV, Marinova EM, Gordon MH, Raneva VG. Antioxidant activity and mechanism of action of thymol and carvacrol in two lipid systems. Food Chemistry 1999;64(1):59-66.

Yu TC, Sinnhuber RO. 2-Thiobarbituric acid adducts of malonaldehyde and trans-mucoaldehyde. Analytical Biochemistry 1986;156:326-333. 